\title{
Liver Transplantation in Man-IV, Haemorrhage and Thrombosis
}

\author{
P. T. FLUTE,* M.D., M.C.PATH. ; M. O. RAKE, $\dagger$ M.B., B.SC., M.R.C.P. ; ROGER WILLIAMS, $\ddagger$ M.D., F.R.C.P. \\ M. J. SEAMAN, $\$$ M.B., B.S.; R. Y. CALNE, M.A., M.S., F.R.C.S.
}

\begin{abstract}
Summary : Blood coagulation and fibrinolytic factors $\checkmark$ have been measured in 13 patients treated by liver transplantation. During operation intravascular coagulation and fibrinolysis were increased, but seldom to a degree which would cause abnormal bleeding. Measurement of the catabolism of radioactive fibrinogen showed that increased intravascular coagulation continued for long periods after the operation. Despite secondarily increased fibrinolysis, there was a high incidence of thrombosis. Treatment with anticoagulants or with fibrinolysis inhibitors may be valuable in these patients.
\end{abstract}

\section{Introduction}

The dangers of operative haemorrhage and later of thrombosis have been reported in relation to liver transplantation by Starzl et al. (1968). They were also a feature of the combined Addenbrooke's Hospital, Cambridge, and King's College Hospital, London, series of transplants. After 13 operations two patients have died of uncontrollable bleeding and another required the transfusion of 50 units of blood. Later, thrombosis of the deep leg veins was clinically evident in two patients, a third died of hepatic artery thrombosis at the site of previous clamping, and superficial thrombophlebitis was noted at the site of venepunctures and infusions in the majority. This paper describes the haematological changes in these patients, who are identified by the same case numbers as in the preceding paper (Williams et al., 1969).

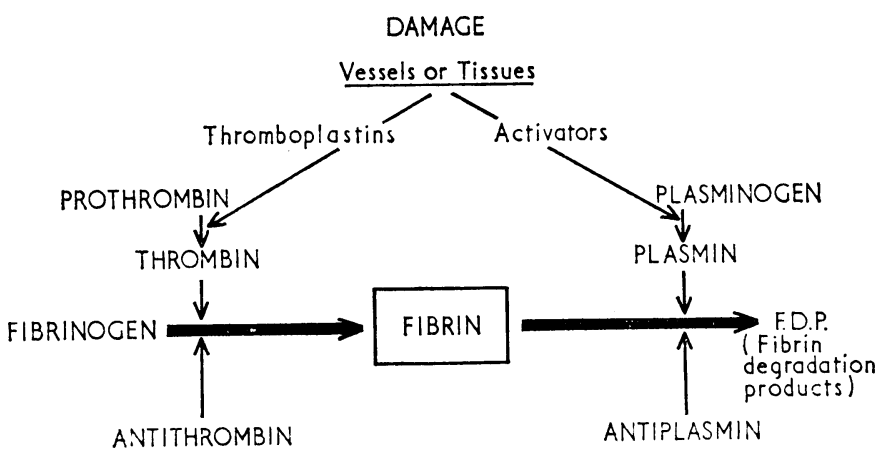

FIG. 1.-Blood coagulation and fibrinolytic factors.

The interrelationship of coagulation and fibrinolysis is illustrated in Fig. 1, where platelets and many of the coagulation factors are grouped as "thromboplastins." Multiple derangements could be expected during and after liver transplantation. Firstly, defective liver synthesis might cause a deficiency of the coagulation factors IX, VII, $\mathrm{X}, \mathrm{V}$, pro-

* Reader in Haematology, King's College Hospital Medical School, London S.E.5.

+ Medical Registrar, King's College Hospital, London S.E.5.

$\ddagger$ Director, Medical Research Council Group on Metabolism and Haemodynamics of Liver Disease, King's College Hospital, London S.E.5.

Assistant Haematologist, University of Cambridge.

|l Professor of Surgery, Addenbrooke's Hospital, Cambridge. thrombin, or fibrinogen (Donaldson et al., 1969). The liver also synthesizes antiplasmins and possibly plasminogen (Sherry, 1968). Secondly, coagulation factors might fall if their consumption is increased by disseminated intravascular coagulation or by excessive fibrinolysis (Rodriguez-Erdmann, 1965).

\section{Methods}

Blood Coagulation.-Fibrinogen was measured gravimetrically (Ingram, 1961) after clotting citrated plasma with thrombin in the presence of calcium and tranexamic acid, the latter to inhibit in-vitro fibrinolysis. Some estimations were performed as a fibrinogen titre (Sharp and Eggleton, 1963). The turnover of human fibrinogen (Kabi) was measured after labelling with ${ }^{125} \mathrm{I}$ as described by Flanc et al. (1968); the intravascular fraction and catabolic rates were calculated according to McFarlane et al. (1964). Standard methods were used for the one-stage coagulation tests of prothrombin time, partial thromboplastin time with kaolin, and thrombin clottingtime; two-stage assay of prothrombin; assay of factor VIII ; and platelet count (Hardisty and Ingram, 1965).

Fibrinolysis.-Circulating activator of plasminogen was measured on bovine fibrin plates (Flute, 1964). In the testing of normal subjects these plates gave areas of lysis between 50 and 100 sq. mm. after 24 hours with the plasma euglobulin fraction, which eliminates the plasma inhibitors, and no lysis with whole plasma. Plasminogen was measured by the caseinolytic assay of Alkjaersig et al. (1959) and fibrin degradation products (F.D.P.) in the serum by the immunological method of Merskey et al. (1966), as modified to use human tanned red cells (Merskey, personal communication, 1968). A reduction in plasma plasminogen below 3 units $/ \mathrm{ml}$. combined with an increase of serum F.D.P. to $3 \mu \mathrm{g}$. $/ \mathrm{ml}$. was taken to indicate an increase of fibrinolysis. When this is associated with an increase of circulating activator this can be described as generalized, to contrast with the situation where circulating activator is normal or decreased, and the fibrinolysis is assumed to be localized to intravascular fibrin.

\section{Results}

\section{Operation and First Day}

Precise data are lacking for Cases 1 and 2, who died soon after the operation, and for Case 13 owing to technical difficulties. In the remaining 10 patients decreased blood platelets and plasma fibrinogen and plasminogen were the usual findings immediately after operation (Table I). Six adult patients presented similar haematological features and may be considered together. The one-stage coagulation tests were normal before operation and prolonged only by a few seconds afterwards. During operation fibrin plates showed lysis with whole plasma up to a maximum of 300 sq. mm. Serum F.D.P. were always increased immediately after operation, ranging between 12 and $48 \mu \mathrm{g} . / \mathrm{ml}$. Blood replacement averaged 16 units. Weighing 
TABLE I.-Findings Before and Immediately After Operation

\begin{tabular}{|c|c|c|c|c|c|c|c|c|c|c|c|}
\hline \multirow{2}{*}{$\begin{array}{l}\text { Case } \\
\text { No. }\end{array}$} & & \multicolumn{3}{|c|}{$\begin{array}{c}\text { Platelets } \\
\left(10^{3} / \text { cu.mm. of Blood }\right)\end{array}$} & \multicolumn{3}{|c|}{$\begin{array}{c}\text { Fibrinogen } \\
\text { (mg./100 ml. of Plasma, or Titre) }\end{array}$} & \multicolumn{3}{|c|}{$\begin{array}{c}\text { Plasminogen } \\
\text { (Units/ml. of Plasma) }\end{array}$} & \multirow{2}{*}{$\begin{array}{c}\text { Blood } \\
\text { for } \\
\text { Transfusion } \\
\text { (Units) }\end{array}$} \\
\hline & & Before & After & $\%$ Change & Before & After & $\%$ Change & Before & After & $\%$ Change & \\
\hline $\begin{array}{r}3 \\
5 \\
7 \\
9 \\
10 \\
12 \\
\end{array}$ & & $\begin{array}{r}350 \\
164 \\
124 \\
160 \\
68 \\
\end{array}$ & $\begin{array}{r}\overline{260} \\
81 \\
52 \\
75 \\
20 \\
\end{array}$ & $\begin{array}{l}-26 \\
-50 \\
-58 \\
-53 \\
-70\end{array}$ & $\begin{array}{c}\text { Titre } 1 / 256 \\
775 \\
360 \\
530 \\
\text { Titre } 1 / 128 \\
170\end{array}$ & $\begin{array}{c}\text { Titre } 1 / 64 \\
370 \\
475 \\
430 \\
\text { Titre } 1 / 128 \\
216\end{array}$ & $\begin{array}{l}-75 \\
-52 \\
+32 \\
-19 \\
-- \\
+27\end{array}$ & $\begin{array}{l}\overline{5 \cdot 2} \\
3 \cdot 2 \\
2 \cdot 5 \\
\overline{4 \cdot 5}\end{array}$ & $\begin{array}{l}-7 \cdot 7 \\
1 \cdot 5 \\
2 \cdot 1 \\
3 \cdot 7\end{array}$ & $\begin{array}{l}- \\
-48 \\
-53 \\
-16 \\
-18\end{array}$ & $\begin{array}{r}16 \\
25 \\
8 \\
13 \\
15 \\
18\end{array}$ \\
\hline Mean & & 173 & 98 & -51 & - & 一 & -14 & $3 \cdot 8$ & 2.5 & -34 & 16 \\
\hline $\begin{array}{l}11 \text { (Child) .. } \\
8 \text { (Hepatic coma) } \\
4 \text { (Hepatoma) } \\
6 \text { (Hepatoma) }\end{array}$ & $\begin{array}{l}\ldots \\
\because \\
\cdots\end{array}$ & $\begin{array}{l}60 \\
65 \\
80 \\
\end{array}$ & $\begin{array}{l}60 \\
76 \\
80 \\
\end{array}$ & $\overline{+17}$ & $\begin{array}{l}\text { Titre } 1 / 128 \\
120 \\
595 \\
\text { Titre } 1 / 256\end{array}$ & $\begin{array}{c}\text { Titre } 1 / 128 \\
225 \\
310 \\
\text { Titre } 1 / 256\end{array}$ & $\begin{array}{l}- \\
+97 \\
-48 \\
-\end{array}$ & $\begin{array}{l}\overline{1 \cdot 2} \\
5 \cdot 7 \\
\end{array}$ & $\begin{array}{l}\overline{2 \cdot 1} \\
2 \cdot 5 \\
\end{array}$ & $\begin{array}{l}-70 \\
+56 \\
-\end{array}$ & $\begin{array}{r}3 \\
19 \\
50 \\
46\end{array}$ \\
\hline Normal range & $\ldots$ & \multicolumn{3}{|c|}{$125-500$} & \multicolumn{3}{|c|}{$220-400 . \quad$ Titre $1 / 128$} & \multicolumn{3}{|c|}{$3-6$} & - \\
\hline
\end{tabular}

the swabs to estimate the rate of blood loss suggested that the bleeding was evenly distributed throughout the operation.

Four patients merit separate consideration (Table I); one a child, one with multiple coagulation defects before operation, and two with major bleeding. Case 11, aged 2 years and 10 months, had a small transfusion, but the actual blood loss was similar to that of the adult patients in relation to his blood volume. Before operation in Case 8 one-stage coagulation tests were prolonged and fibrinogen and platelets were low (Fig. 2).

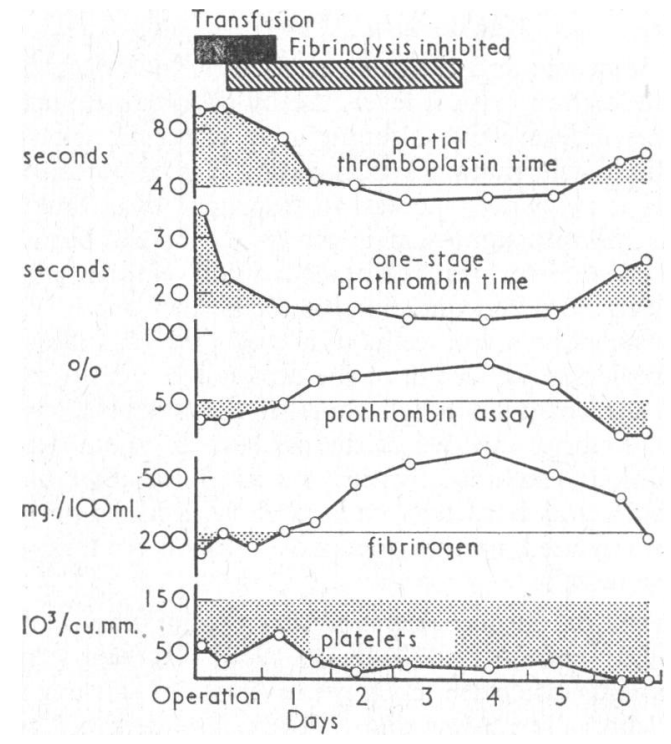

FIG. 2.-Case 8. Blood coagulation changes from before operation to death on day 6 .

Factor VIII was raised to $263 \%$. Plasma activator was decreased, plasminogen was low $(1 \cdot 2$ units $/ \mathrm{ml}$.), and F.D.P. were high $(8 \mu \mathrm{g} . / \mathrm{ml}$.). The coagulation defects were easily corrected by mixing with normal plasma in the laboratory but improved only slightly in the patient after the transfusion of $8 \mathrm{~g}$. of fibrinogen and 1.5 litres of fresh frozen plasma. Tranexamic acid (Cyklokapron) was given to inhibit fibrinolysis, $1 \mathrm{~g}$. intravenously before and four-hourly during the operation, and then $0.5 \mathrm{~g}$. every six hours for three days. Blood loss was only slightly above average, and after operation the values for the platelets, fibrinogen, and plasminogen had increased. Cases 4 and 6 each required more than 46 units of blood at operation. Both had large hepatomas with numerous vascular adhesions and collateral blood vessels. Blood loss was heavy from the beginning. One patient (Case 6) died of uncontrollable bleeding, though plasma fibrinogen did not fall below critical levels. The findings immediately after operation in Case 4 were similar to those in the first group despite the heavy bleeding (Table I ; see also Calne et al., 1968).

\section{First Postoperative Week}

Complete investigations are available for seven patients (Table II). Daily blood samples were examined, and within the first 48 hours the one-stage coagulation tests had returned

\begin{tabular}{|c|c|c|c|c|c|c|c|c|c|}
\hline \multirow{2}{*}{$\begin{array}{c}\text { Case } \\
\text { No. }\end{array}$} & \multicolumn{2}{|c|}{$\begin{array}{c}\text { Platelets } \\
\left(10^{3} / \mathrm{cu} . \mathrm{mm} .\right.\end{array}$} & \multicolumn{2}{|c|}{$\begin{array}{c}\text { Fibrinogen } \\
\text { (mg./100 ml.) }\end{array}$} & \multicolumn{2}{|c|}{$\begin{array}{c}\text { Prothrombin } \\
(\%)\end{array}$} & \multicolumn{2}{|c|}{$\begin{array}{l}\text { Plasminogen } \\
\text { (units/ml.) }\end{array}$} & \multirow{2}{*}{$\begin{array}{l}\text { F.D.P. } \\
\text { (ug/mi.) } \\
7 \text { th day }\end{array}$} \\
\hline & 1st day & 7th day & highest & 7th day & 1st day & 7th day & highest & 7th day & \\
\hline $\begin{array}{r}4 \\
5 \\
7 \\
8 \\
9 \\
11 \\
12\end{array}$ & $\begin{array}{r}80 \\
264 \\
251 \\
76 \\
97 \\
160 \\
258\end{array}$ & $\begin{array}{r}22 \\
24 \\
33 \\
9 \\
20 \\
65 \\
34\end{array}$ & $\begin{array}{l}470 \\
510 \\
475 \\
610 \\
740 \\
310 \\
510\end{array}$ & $\begin{array}{l}170 \\
160 \\
300 \\
375 \\
200 \\
100 \\
270\end{array}$ & $\begin{array}{l}50 \\
52 \\
56 \\
45 \\
56 \\
95 \\
46\end{array}$ & $\begin{array}{r}96 \\
85 \\
100 \\
73 \\
100 \\
100 \\
104\end{array}$ & $\begin{array}{l}1 \cdot 8 \\
1.3 \\
2 \cdot 0 \\
2 \cdot 1 \\
2.5 \\
\frac{5.6}{2}\end{array}$ & $\begin{array}{l}1 \cdot 2 \\
1 \cdot 0 \\
2 \cdot 0 \\
1 \cdot 1 \\
2 \cdot 0 \\
4 \cdot 5\end{array}$ & $\begin{array}{r}12-24 \\
6-12 \\
9-34 \\
8-16 \\
12-96 \\
6-12 \\
6-24\end{array}$ \\
\hline
\end{tabular}

to normal, and platelet count, fibrinogen, and prothrombin had begun to rise. The factor VIII concentration also increased to between 200 and $500 \%$, and there was a neutrophil leucocytosis with a shift to the left and toxic granulation of the neutrophils. Subsequently prothrombin and factor VIII continued to increase, but there was a sharp drop of fibrinogen and platelets, beginning between the third and fifth days, which usually coincided with deterioration in biochemical tests of liver function. In three of these patients marrow was aspirated at the time of the low platelet count and shown to contain numerous megakaryocytes. The $\mathrm{T}^{\frac{1}{2}}$ of labelled fibrinogen was 70 hours before operation in Case 12 ; during the first week this had decreased to 37 hours. The fibrinogen $\mathrm{T}^{\frac{1}{2}}$ of Case 10 was 31 hours in the first week, again below the laboratory normal of 75 to 90 hours. Case 8 showed an even shorter $T^{\frac{1}{2}}$ of fibrinogen, of the order of seven hours on the fifth and sixth days (Table III). During the whole week plasma euglobulin failed to lyse fibrin plates, plasminogen remained below normal except in Case 12, and F.D.P. remained high.

\begin{tabular}{|c|c|c|c|c|c|}
\hline $\begin{array}{c}\text { Weeks } \\
\text { after } \\
\text { Transplant }\end{array}$ & $\begin{array}{l}\text { Case } \\
\text { No. }\end{array}$ & $\begin{array}{c}\text { Fibrinogen } \\
\text { (mg./100 ml. } \\
\text { of Plasma) }\end{array}$ & $\begin{array}{c}\mathrm{T}_{2}^{1} \\
\text { (hours) }\end{array}$ & $\begin{array}{c}\text { Intravascular } \\
\text { Fraction } \\
(\%)\end{array}$ & $\begin{array}{l}\text { Fractional* } \\
\text { Catabclic } \\
\text { Rate }(\%)\end{array}$ \\
\hline $\begin{array}{r}1 \\
2 \\
3-4\end{array}$ & $\left\{\begin{array}{r}8 \\
10 \\
12 \\
9 \\
9 \\
4 \\
7 \\
11 \\
4 \\
10 \\
12\end{array}\right.$ & $\begin{array}{l}385 \\
300 \\
400 \\
200 \\
225 \\
215 \\
200 \\
310 \\
240 \\
290 \\
550\end{array}$ & $\begin{array}{c}\text { Approx. } 7 \\
31 \\
37 \\
30 \\
51 \\
32 \\
18 \\
35 \\
48 \\
84 \\
42\end{array}$ & $\begin{array}{l}-\overline{83} \\
84 \\
62 \\
80 \\
84 \\
86 \\
55 \\
78 \\
82 \\
70\end{array}$ & $\begin{array}{r}65 \\
55 \\
90 \\
41 \\
62 \\
108 \\
87 \\
44 \\
24 \\
57\end{array}$ \\
\hline $\begin{array}{l}5 \text { patients with } \\
\text { Mean } \\
\text { Range }\end{array}$ & $\begin{array}{r}\text { rrhosis: } \\
\quad \ldots \\
\quad \ldots\end{array}$ & $\begin{array}{c}209 \\
155-260\end{array}$ & $\begin{array}{c}79 \\
63-95\end{array}$ & $\begin{array}{c}78 \\
72-90\end{array}$ & $\begin{array}{c}28 \\
23-33\end{array}$ \\
\hline
\end{tabular}

Recurrent gastrointestinal haemorrhage occurred in Cases 5 and 11 , though the haematological firdings were no different in these patients. Bleeding coincided with a rising blood urea, 
to over $200 \mathrm{mg} . / 100 \mathrm{ml}$. in each case. In Case 5 the bleeding stopped when the blood urea was reduced by peritoneal dialysis, only to recur when it rose again. In Case 11 aminocaproic acid was given to inhibit fibrinolysis on day $6,1 \mathrm{~g}$. intravenously followed by $0.5 \mathrm{~g}$. six-hourly. Bleeding stopped within 24 hours and platelets and fibrinogen rose progressively. Aminocaproic acid was continued for the 11 days until he died, but three days after it was started his haemoglobin fell from 8.8 to $6.5 \mathrm{~g} . / 100 \mathrm{ml}$. without further bleeding, fragmented red cells were noted for the first time, and reticulocytes increased to $20 \%$. Heparin 200 units subcutaneously every six hours was added to the treatment, and reticulocytes had fallen to $8 \%$ by the time of his death from pneumonia four days later. Fibrinogen $\mathrm{T}_{\frac{1}{2}}$ was 35 hours while he was receiving aminocaproic acid and heparin (Table III).

Case 8, who died suddenly from acute rejection, showed on the day of his death a considerable drop of fibrinogen and prothrombin and prolonged one-stage coagulation tests (Fig. 2). Platelets, which had been low, fell further. There was no fibrin-plate lysis, plasminogen remained low, and F.D.P. increased from 10 to $16 \mu \mathrm{g} . / \mathrm{ml}$.

\section{Later Changes}

The results of weekly investigations are available for six survivors (excluding Case 11). When biochemical tests showed impaired liver function, which was common between the fifth and the twenty-eighth day, plasma prothrombin and blood platelets tended to fall. When the biochemical tests returned to normal these changes were reversed (Fig. 3), but the other

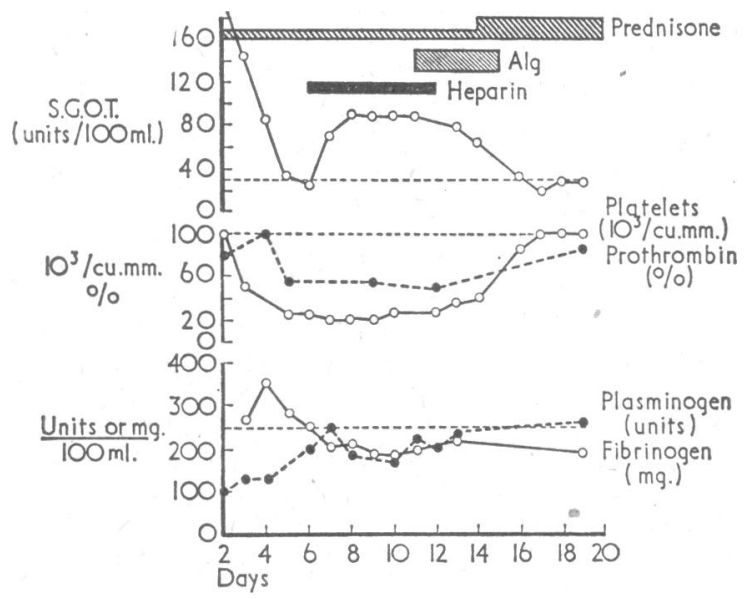

FIG. 3.-Case 9. Blood changes during the first three weeks after operation.

abnormal haematological findings were more persistent. Factor VIII remained between 175 and $490 \%$ throughout the period of observation. Fibrinogen stayed within the range 160 to 270 mg. $/ 100 \mathrm{ml}$. of plasma except in three patients when values between 450 and $500 \mathrm{mg} . / 100 \mathrm{ml}$. were recorded in association with infection. Fibrin plates showed that activator was normal or decreased while plasminogen remained low, range 1 to 3 units $/ \mathrm{ml}$., and F.D.P. high, 3 to $16 \mu \mathrm{g} . / \mathrm{ml}$. Turnover of labelled fibrinogen (Table III) remained increased in every patient tested except that it had returned to normal by the third month in Case 10, at a time when all the other tests were also within the normal range.

\section{Discussion}

Accelerated loss of plasma fibrinogen may be due to external bleeding, shifts to the extravascular fluid, increased intra- vascular coagulation in response to the stimulus provided by damaged cells (McKay, 1963), or, less commonly, to an increase of circulating activator of fibrinolysis large enough to give generalized proteolysis (Sherry, 1968). The decrease of fibrinogen usually found immediately after liver transplantation suggests an accelerated loss during the operation which could be due to any combination of these causes. Care was taken to replace blood losses as completely as possible, and in the later stages of each operation $4 \mathrm{~g}$. of fibrinogen concentrate (Lister Institute of Preventive Medicine), at least 5 units of fresh blood, and often 1 litre of fresh frozen plasma were included in the transfusion fluids. This should have ensured an adequate supply of all blood constituents if these had not been further depleted by one or more of the other mechanisms.

The associated fall of blood platelets could not be accounted for by fibrinolysis, and it seems likely, therefore, that intravascular coagulation is the major cause. The observed increase of fibrinolysis was moderate in degree. Increases of circulating activator may be transient, and could have been missed in the present studies, but a better measure of overall fibrinolysis is given by the fall in plasminogen, which is only slowly replaced by fresh synthesis, and by the increase in serum F.D.P., since at least some of these fragments have a half-life of nine hours in the circulation (Sherry, 1968). The changes in both plasminogen and F.D.P. found immediately after operation are regularly exceeded in patients treated with another fibrinolytic activator, streptokinase, in amounts which do not give generalized proteolysis (Kakkar et al., 1969).

When platelets and coagulation factors, including fibrinogen, fall below certain critical levels the blood becomes incoagulable, and shock and massive bleeding may occur in what has been called the "defibrination syndrome." It is important to recognize this state, since successful treatment often requires that the stimulus to coagulation is removed. It has been described in relation to liver transplantation (Von Kaulla et al., 1966) and was encountered once in this series, in Case 1. The cause was probably the severe cellular necrosis which followed a prolonged period of ischaemia of the donor liver. In the remaining patients the coagulation fell short of the degree likely to cause massive bleeding. In two of the patients in whom defibrination was definitely excluded (Cases 4 and 6) another explanation has to be found for their massive blood loss. The latter may have been related to the presence of blood under pressure in collateral vessels.

Subacute or chronic intravascular coagulation is now being increasingly recognized (McKay, 1968). It was suspected in these patients when the postoperative rise of plasma fibrinogen was cut short after a few days. The subsequent fall could have been due to decreased hepatic synthesis or accelerated catabolism. An increase in the fractional catabolic rate of fibrinogen was confirmed by studies with the labelled protein. The extravascular distribution of fibrinogen was also increased in two of the patients, but fell within the normal range in eight, suggesting that the main catabolism was intravascular. Other evidence suggests that it is mainly due to increased coagulation; platelets were decreased simultaneously, at a time when their production by the marrow was increased, and the increased plasma concentration of factor VIII is another typical feature of intravascular coagulation (Penick et al., 1965).

The increase of fibrinolysis observed was of the localized type, with low plasminogen, high F.D.P., and normal or often reduced plasma activator, and probably represented a protective mechanism, tending to prevent the formation of thrombi. Though platelets and prothrombin returned to normal after the control of the early rejection phenomena, the other evidence of intravascular coagulation-high factor VIII and a localized increase of fibrinolysis-continued for long periods. Fibrinogen catabolism was still increased in all the patients who showed these changes in whom it was measured, though to a lesser degree in the later weeks. Only Case 10 showed a complete return to normal. 
These findings are important, since they are likely to indicate continuing cellular damage. It should be emphasized that any cause of major cellular necrosis might produce such effects and they should not be considered as specific indicators of rejection. They are of clinical significance, for they will produce a tendency to thrombosis, particularly at sites of vascular damage or of stasis in blood flow. Major vessels may be concerned, but thrombi were also found in the small vessels of the lung and gastrointestinal tract at necropsy in three patients. If hepatic vessels were obstructed the resultant ischaemia could contribute to further liver damage.

Both fibrinolysis and coagulation can be influenced by treatment with the appropriate inhibitors. Inhibitors of fibrinolysis may be dangerous when intravascular coagulation is in progress, but have been used in two patients. In Case 8 pre-existing hepatic damage had produced haematological changes very suggestive of intravascular coagulation. Major deficiencies could not be replaced by transfusion before operation and tranexamic acid was given empirically. The more logical choice of heparin was considered, but was rejected in view of the major vascular anastomoses to be made. Excision of the damaged liver removed the stimulus to coagulation, and this together with the therapy given prevented major bleeding. Gastrointestinal bleeding complicated the early course of case 11 , and fibrinolysis was inhibited with aminocaproic acid. Bleeding stopped, but after a few days anaemia developed with all the characteristics of the microangiopathic haemolysis known to be sometimes associated with intravascular fibrin (Brain et al., 1962 ; Baker et al., 1968). It seems likely that the inhibition of fibrinolysis allowed the deposition of macroscopic fibrin. Three patients have been treated with heparin. This was given shortly before the death of the patient in Case 8, too late to affect the final outcome; to Case 11, when it appeared to decrease the severity of the microangiopathic haemolytic anaemia ; and to Case 9 at the time of deepvein thrombosis. It may be that continuous anticoagulants may improve the prognosis, but this has yet to be established.
We wish to thank Professor W. M. Davidson for his advice and encouragement. Human fibrinogen for the radioactive studies and tranexamic acid were kindly supplied by Kabi Pharmaceuticals. Grants were received from King's College Hospital Medical School Research Committee and from Pfizer Ltd. Miss G. Pannell gave skilled technical assistance.

\section{REFERENCES}

Alkjaersig, N., Fletcher, A. P., and Sherry, S. (1959). fournal of Clinical Investigation, 38, 1086.

Baker, L. R. I., Rubenberg, M. L., Dacie, J. V., and Brain, M. C. (1968). British fournal of Haematology, 14, 617.

Brain, M. C., Dacie, J. V., and Hourihanc, D. O'B. (1962). British fournal of Haematology, 8, 358.

Calne, R. Y., et al. (1968). British Medical Gournal, 4, 541.

Donaldson, G. W. K., Davies, S. H., Darg, A., and Richmond, J. (1969). fournal of Clinical Pathology, 22, 199.

Flanc, C., Kakkar, V. V., and Clarke, M. B. (1968). British fournal of Surgery, 55, 742.

Flute, P. T. (1964). British Medical Bulletin, 20, 195.

Hardisty, R. M., and Ingram, G. I. C. (1965). Bleeding Disorders, p. 255. Oxford, Blackwell Scientific.

Ingram, G. I. C. (1961). Fournal of Clinical Pathology, 14, 356.

Kakkar, V. V., Flanc, C., Howe, C. T., O'Shea, M., and Flute, P. T. (1969). British Medical fournal, 1, 806.

McFarlane, A. S., Todd, D., and Cromwell, S. (1964). Clinical Science, 26, 415 .

McKay, D. G. (1968). Proceedings of the Royal Society of Medicine, 61, 1129.

Merskey, C., Kleiner, G. J., and Johnson, A. J. (1966). Blood, 28, 1.

Penick, G. D., Roberts, H. R., and Dejancv, I. I. (1965). Federation Proceedings, 24, 835.

Rodriguez-Erdmann, F. (1965). New England Fournal of Medicine, 273, 1370.

Sharp, A. A., and Eggleton, M. J. (1963). Foumal of Clinical Pathology, 16, 551 .

Sherry, S. (1968). Annual Reviews of Medicine, 19, 247.

Starzl, T. E., et al. (1968). Surgery, 63, 549.

Von Kaulla, K. N., Kaye, H., Von Kaulla, E., Marchioro, T. L., and Starzl, T. E. (1966). Archives of Surgery, 92, 71.

Williams, R., et al. (1969). British Medical fournal, 3,

\section{Nitrazepam-a Safe Hypnotic}

HENRY MATTHEW,* M.D., F.R.C.P.ED. ; A. T. PROUDFOOT, $\dagger$ M.B., B.SC., M.R.C.P.ED.

R. C. B. AITKEN, $\ddagger$ M.D., M.R.C.P.ED., D.P.M. ; J. A. RAEBURN,§ M.B., M.R.C.P.ED. ; N. WRIGHT,\| M.B., B.sC.

British Medical Fournal, 1969, 3, 23-25

Cummary : In 27 patients nitrazepam (Mogadon) taken $\checkmark$ in acute overdosage produced no untoward effects except drowsiness, even when 80 tablets were consumed. A double-blind trial in patients in general medical wards established that nitrazepam was as effective as butobarbitone as a hypnotic. It is concluded that nitrazepam is a safe and effective hypnotic.

* Consultant Physician.

$\dagger$ Formerly Registrar.

₹ Senior Lecturer, University Department of Psychiatry, Royal Edinburgh Hospital, Morningside Park, Edinburgh.

Formerly Senior House Officer.

II Registrar. Regional Poisoning Treatment Centre, Royal Infirmary, Edinburgh EH3
9YW.

\section{Introduction}

The criteria for the acceptability of a hypnotic should be demanding. They obviously include a reasonable certainty that adequate sleep will be induced, but lack of confusion or hangover and absence of dependence, drug rashes, and other adverse effects are equally important. In addition the rapid rise in the incidence of self-poisoning with sedative drugs (Scottish Health Services Council, 1968) makes it highly desirable to have available an effective hypnotic which is safe in overdose. At first sight such an aim is a pharmacological paradox, as a drug which in therapeutic doses will effectively induce sleep is unlikely at the same time to be safe in overdosage. This is certainly true of barbiturates (Setter et al., 